\title{
Efficiency Analysis of Paddy Production in Tank Irrigated Systems of Southern Zone in Tamil Nadu, India
}

\author{
R. Vasanthi ${ }^{1 *}$, B. Sivasankari ${ }^{2 *}$, J. Gitanjali ${ }^{3}$ and R. Paramasivam ${ }^{4}$ \\ ${ }^{1}$ Agricultural College and Research Institute, Killikulam, Tamil Nadu, India \\ ${ }^{2}$ Agricultural College and Research Institute, Madurai, Tamil Nadu, India \\ ${ }^{3}$ Agricultural Engineering College and Research Institute, Coimbatore, Tamil Nadu, India \\ ${ }^{4}$ Kumaraguru Institute of Agriculture, Erode, Tamil Nadu Agricultural University, \\ Tamil Nadu, India \\ *Corresponding author
}

\section{A B S T R A C T}

\begin{tabular}{l} 
Key w or d s \\
Rice, tank, \\
Technical \\
Efficiency, OLS, \\
Maximum likely \\
hood estimation, \\
Stochastic Frontier. \\
\hline Article Info \\
\hline Accepted: \\
17 May 2017 \\
Available Online: \\
10 June 2017
\end{tabular}

\section{Keywords}

Rice, tank Technical

Efficiency, OLS, Maximum likely hood estimation, Stochastic Frontier

Accepted:

17 May 2017

10 June 2017
The study employed a Stochastic Frontier Production approach to find the determinants that can enhance the production of rice in the Southern zone of Tamil Nadu. The data collected for two years (2009-10 and 2010-11) under the Cost of Cultivation Scheme of Tamil Nadu Centre were used for the study. The results of stochastic production function indicate the input variables seed, fertilizer nutrients (NPK), labour hours, Machine hours and pesticide are significant and hence, playing a major role in rice production. The coefficient of seed is negative and highly significant indicating that to get better yield in tank irrigated farms the farmers may reduce the usage of seed. The coefficient of pesticide is also negative and highly significant indicates that to increase the yield we could reduce the pesticide usage since, it will lead to soil damage. It is advisable to increase the usage of labour and machine hours in tank irrigated farms to get better yield. The average fertilizer (NPK) rate is $203.4 \mathrm{~kg}$ per acre which is higher than the recommended level of $114 \mathrm{~kg}$ of NPK nutrients. However, proper combination of $\mathrm{N}, \mathrm{P}$, and $\mathrm{K}$ as recommended is $114 \mathrm{~kg}$ of NPK. The results of inefficiency model suggest that the age of the head of household increases the inefficiency level decreases. Rice farmers are 14 percent technically inefficient, implying that little potential exists that can be explored through improvement in resource use efficiency.

\section{Introduction}

Rice is the stable food of over half the world's population. Rice is one of the most important food crops of India contributing to 43 per cent of total food grains production in the country. The rice harvesting area in India is the world's largest. The major rice growing States are West Bengal, Uttar Pradesh, Andhra Pradesh, Punjab, Tamil Nadu, Orissa, Bihar and Chhattisgarh, which together contribute about
72 per cent of the total area and 76 per cent of the total production in the country. In Tamil $\mathrm{Nadu}$, rice is grown over an area of 18 lakh to 20 lakh hectares annually primarily in tank irrigated conditions.

The present study undertaken in Southern zone in the state of Tamil Nadu has estimated the resource use efficiency in rice production 
under tank irrigated farms and has assessed the effect of farm specific socio economic factors affecting the technical efficiency. Technical efficiency is an indicator of the productivity of the farm and the variation in technical efficiency can reflect the productivity difference across farms. Usually the Stochastic frontier production functions are estimated by using maximum likelihood estimation. But, in this study the existence of inefficiency were tested using Log likelihood ratio test. The Stochastic frontier production function is used to evaluate the performance efficiency of paddy farms in tank irrigated conditions. The specific objective of the paper is to apply Stochastic Frontier Analysis technique and to test the presence of inefficiency effects and finally to estimate the technical efficiencies of the firms over time in tank irrigated farms.

\section{Sampling and data collection}

Southern zone was selected purposively for this study. The sample holdings for analysis in the present study were fixed ultimately based on the fact that these had grown paddy in the two years (2009-10 and 2010-11). The data collected under the cost of cultivation scheme were used. Under the scheme a stratified random sampling method was adopted. Sivagangai, Viruthunagar and Tirunelveli districts were covered for Tank irrigation under the above scheme during the two consecutive years from 2009-10 and 2010-11. Total number of sample cultivating paddy in both the years was 53 and the total observations were fixed at 106.

\section{Materials and Methods}

Using parametric approaches to production, technical efficiency for paddy were estimated for the sample farms for which, a stochastic production function was employed. Technical efficiency obtained in this manner serves a relative measure, where the production frontier is defined by the farmers holdings included in its estimation.

In the present study, the stochastic frontier production function approach was used to measure Technical efficiency of rice cultivating farms (Aigner et al., 1977; Kalirajan and Shand, 1989; Sharma and Dutta, 1997). In analyzing technical efficiency, it is not the average output, but the maximum possible output obtainable from a given bundle of inputs, is of importance. The frontier production function is defined as the maximum possible output that a farm can produce from a given level of inputs and technology. In stochastic frontier, the disturbance term is decomposed into two components: asymmetric component which captures randomness outside the control of the farmer, such as droughts, floods, etc. and the statistical noise contained in every empirical relationship and the other one-sided component capturing randomness under the control of the farmer (i.e., inefficiency).

Stochastic frontier production function was first formulated by Aigner et al., (1977) and Meeusen and van den Broek (1977). Assuming that each farm uses $m$ inputs (vector $\mathrm{x}$ ) and produces a single output $\mathrm{y}$, the production technology of the ith farm is specified by the stochastic frontier production function

$y_{i}=f\left(x_{i} ; \beta\right) \exp \left(\varepsilon_{i}\right)$

where $i=1,2, \ldots . n$ refers to farms, $\square$ is a vector of parameters and $\square \mathrm{i}$ is an error term and the function is called the 'deterministic kernel'. The frontier is also called as 'composed error' model because the error term $\square \mathrm{i}$ is asumed to be the difference of two independent elements,

$\varepsilon_{i}=v_{i}-u_{i}(2)$ 
where vi is a two sided error term representing statistical noise such as weather, strikes, luck, etc., which are beyond the control of the farm and is the difference between maximum possible stochastic output (frontier) and actual output yi. Thus ui represents output oriented technical inefficiency. Thus, the error term $\square \mathrm{i}$ has an asymmetric distribution. From (1) and (2), the farm-specific output-oriented technical efficiency can be shown as

$$
T E_{i}^{o}=\exp \left(-u_{i}\right)=y_{i} /\left\{f\left(x_{i} ; \beta\right) \exp \left(v_{i}\right)\right\}
$$

Since, and hence. When ui $=0$ the farm's output lies on the frontier and it is 100 per cent efficient. Thus, the output oriented technical efficiency tells how much maximum output is possible with the existing usage levels of inputs.

In the literature the common functional forms used to represent the deterministic kernel are 'Cobb-Douglas' and 'Translog'. The 'CobbDouglas' function in log form is given by

$\ln \left(y_{i}\right)=X_{i} \beta+v_{i}-u_{i}, i=1,2, \ldots n$

where is a vector consisting of the logarithms of $m$ inputs.

The firm-specific inefficiencies, uit are specified by

$$
u_{i t}=z_{i t} \delta+w_{i t}
$$

and are assumed to be non-negative and independently distributed random variables such that uit is obtained by truncation at zero of the normal distribution with mean and variance $\sigma 2$, where is a vector of explanatory variables associated with technical inefficiency of production of firms over time and $\delta$ is a vector of unknown coefficients. In other words, wit are defined by truncation of the normal distribution with zero mean and variance $\sigma 2$. The technical efficiency of production for the ith firm at the th time period is given by

$$
T E_{i t}=\exp \left(-z_{i t} \delta-w_{i t}\right)
$$

The generalized likelihood test was applied to test a number of hypotheses. The relevant test statistic was calculated using the formula

$$
L R=-2\left\{\ln \left[L\left(H_{0}\right)\right]-\ln \left[L\left(H_{1}\right)\right]\right\}
$$

Where; LR- Log likelihood ratio $\mathrm{L}(\mathrm{H} 0)$ and $\mathrm{L}(\mathrm{H} 1)$ : the values of the likelihood function under the null and alternative hypotheses respectively.

The computer programme FRONTIER 4.1 (Coelli, 1996) was used to estimate simultaneously the parameters of the stochastic production frontier and the technical inefficiency effects.

\section{Results and Discussion}

\section{Empirical model}

In the present study, both Cobb-Douglas production function was initially considered to study the technical efficiency among rice farms.

$\ln y_{i}=\beta_{0}+\sum_{j} \beta_{j} \ln x_{j}, \mathrm{j}=1,2,3 \ldots 5$ (Cobb-

Douglas type)

$\mu=\delta_{0}+\sum_{i=1}^{3} \delta_{i} z_{i} \quad$ (Linear type)

Where,

$\mathrm{y}=$ Yield of paddy (quintal /ha)

Seed $(\mathrm{x} 1)=$ Quantity of seeds $(\mathrm{kg}$. /ha.)

Fer $(\mathrm{x} 2)=$ Quantity of NPK nutrients $(\mathrm{kg}$. /ha.) 
Lab $(x 3)=$ Human labour (hrs. /ha.)

Mach (x4) = Machine hours (hrs. /ha.)

Pes $(\mathrm{x} 5)=$ Cost of plant protection (Rs.

/ha.)

Age $(\mathrm{z} 1)=\quad$ Age of the farmer in years

Household size $(\mathrm{z} 2)=$ Size of the farmer's household (number of family members)

Farm Size $(\mathrm{z} 3)=\quad$ Area in hectares

\section{Mean yield and input use levels in sample} farms

The average yield of rice in the sample farms under tank irrigation worked out to 53.4 quintal per hectare. The tank irrigated farmers used seed on an average of $76.7 \mathrm{~kg} / \mathrm{ha}$.

The average age of the farm decision maker is observed to be 50.8 years of old, indicating that majority of the old people are involved in farming activities.

The mean farm size is 0.6 ha. The average fertilizer (NPK) rate is $203.4 \mathrm{~kg}$ per acre which is higher than the recommended level of $114 \mathrm{~kg}$ of NPK.

However, proper combination of $\mathrm{N}, \mathrm{P}$, and $\mathrm{K}$ as recommended is $114 \mathrm{~kg}$ of NPK. Is not being followed by the farmers, results presented in table 1 that shows a sum Rs. 1412.8 was spent per hectare on pesticide. The labour use was found to be $630.5 \mathrm{hrs} / \mathrm{ha}$ and in the case of machine hours on an average $12.8 \mathrm{hrs} / \mathrm{ha}$ was used.

To analyze the factors to increase the technical efficiency of paddy production in tank irrigated farmers Frontier 4.1 was established for the data and the results are presented in table 2. The results of Ordinary Least Squares (OLS) and Maximum
Likelihood Estimates (MLE) for CobbDouglas production function are reported in table 2 which can be used to test the null hypothesis H0: $\gamma=0$, i.e. no technical efficiency exists in rice production.

It should be noted that the values of loglikelihood function for the full stochastic frontier model and the OLS fit are calculated to be 76.7044 and 65.4577 respectively and reported in table 2. This implies that the generalized likelihood-ratio statistic for testing the absence of technical inefficiency effect from the frontier is calculated to be LR $=-2 *(65.4577-76.7044)=22.4924$ which is estimated by the Frontier 4.1 and reported as the "LR" test of the one sided error.

The degrees of freedom for this test are calculated as $q+1$, where $q$ is the number of parameters, other than $\gamma$ specified to be zero in $\mathrm{H} 0$, thus in our case $\mathrm{q}=5$. The value of "LR" test is significant because it exceeds from the tabulated value taken from Kodde and Palm (1986).

The log likelihood ratio test indicates that inefficiency exists in the data set and therefore, null hypothesis of no technical inefficiency in rice production is rejected. (Abedullah et al., 2007) The coefficients of different input variables estimated with MLE technique are reported in last column of table 2.

The parameters of Cobb-Douglas production function can be directly illustrated as production elasticities of inputs in the production process. The input variables seed, fertilizer nutrients (NPK), labour hours, Machine hours and pesticide are significant and hence, playing a major role in rice production. 
Table.1 Mean yield and input use levels in the tank irrigated paddy farms

\begin{tabular}{|c|c|c|c|c|c|c|}
\hline Year & \multicolumn{2}{|c|}{ 2009-10 } & \multicolumn{2}{|c|}{ 2010-2011 } & \multicolumn{2}{|c|}{$2009-10 \& 2010-11$} \\
\hline Measures & Mean & SD & Mean & SD & Mean & SD \\
\hline $\begin{array}{l}\text { Yield } \\
\text { (quintal/ha) }\end{array}$ & 54.3 & 9.8 & 52.4 & 9.3 & 53.4 & 9.6 \\
\hline \multicolumn{7}{|c|}{ Inputs used in paddy cultivation in Southern zone } \\
\hline Seed (kg/ha) & 78.6 & 13.6 & 74.8 & 13.7 & 76.7 & 13.7 \\
\hline $\begin{array}{l}\mathrm{N}, \mathrm{P}, \mathrm{K} \\
\text { nutrients } \\
(\mathrm{kg} / \mathrm{ha})\end{array}$ & 214.6 & 45.9 & 192.2 & 48.7 & 203.4 & 48.4 \\
\hline $\begin{array}{l}\text { Labour } \\
\text { (Hrs/ha) }\end{array}$ & 620 & 172.5 & 640.9 & 236.6 & 630.5 & 206.3 \\
\hline $\begin{array}{l}\text { Machine } \\
\text { (Hrs/ha) }\end{array}$ & 12.1 & 6.2 & 13.5 & 10.5 & 12.8 & 8.6 \\
\hline $\begin{array}{l}\text { Pesticide } \\
\text { (Rs/ha) }\end{array}$ & 1016.9 & 402.2 & 1808.8 & 2450 & 1412.8 & 1792 \\
\hline \multicolumn{7}{|c|}{ Socio Economic variables } \\
\hline Age & 50.3 & 12.2 & 51.3 & 12.2 & 50.8 & 12.1 \\
\hline $\begin{array}{l}\text { Household } \\
\text { size }\end{array}$ & 5.1 & 2.0 & 5.2 & 2.0 & 5.1 & 2 \\
\hline $\begin{array}{l}\text { Area of the } \\
\text { farm(ha) }\end{array}$ & 0.6 & 0.4 & 0.5 & 0.4 & 0.6 & 0.4 \\
\hline
\end{tabular}

Table.2 OLS and maximum likelihood estimates of the Cobb Douglas Stochastic Frontier function

\begin{tabular}{|c|c|c|}
\hline Production coefficient & OLS coefficients & MLE coefficients \\
\hline Intercept & $3.1515(6.6050)$ & $2.5390(5.1249)$ \\
\hline Seed (kg/ha) & $-0.3296^{* * * *}(4.2969)$ & $-0.2912^{* * * *}(4.0888)$ \\
\hline $\begin{array}{l}\mathrm{N}, \mathrm{P}, \mathrm{K} \text { nutrients } \\
(\mathrm{kg} / \mathrm{ha})\end{array}$ & $0.1766^{* * * *}(3.3440)$ & $0.2314^{* * *}(4.4205)$ \\
\hline Labour (Hrs/ha) & $0.2342^{* * * * * *}(4.4972)$ & $0.2820^{* * * * * 2}(5.2783)$ \\
\hline Machine (Hrs/ha) & $0.0500^{* *}(1.7008)$ & $0.0509^{* * *}(2.1126)$ \\
\hline Pesticide (Rs/ha) & $-0.0451^{* * *}(1.9057)$ & $-0.0470^{* * * *}(2.0845)$ \\
\hline$\sigma^{2}$ & 0.0180 & $0.0141^{\text {**** }}(7.56)$ \\
\hline$\gamma$ & 0.793 & $0.8126^{* * *}(8.07)$ \\
\hline Log likelihood function & 65.4577 & 76.7044 \\
\hline \multicolumn{3}{|l|}{ Inefficiency effect model } \\
\hline Intercept & & $0.4849(7.8503)$ \\
\hline Age & & $-0.0050^{* * * *}(5.9709)$ \\
\hline $\begin{array}{l}\text { Household } \\
\text { size }\end{array}$ & & $-0.0046^{\mathrm{ns}}(0.6449)$ \\
\hline Area of the farm(ha) & & $-0.1216^{* * *}(2.9623)$ \\
\hline
\end{tabular}


Table.3 Frequency distribution of technical efficiency for individual farms

\begin{tabular}{|c|c|c|c|}
\hline \multirow{2}{*}{ Efficiency interval } & \multicolumn{3}{|c|}{ Frequency } \\
\cline { 2 - 4 } & $\mathbf{2 0 0 9 - 1 0}$ & $\mathbf{2 0 1 0 - 1 1}$ & $\mathbf{2 0 0 9 - 1 0 ~ \& ~ 2 0 1 0 - 1 1}$ \\
\hline $0.900<\mathrm{TE}<1.00$ & 12 & 15 & 27 \\
\hline $0.800<\mathrm{TE}<0.900$ & 30 & 24 & 54 \\
\hline $0.700<\mathrm{TE}<0.800$ & 8 & 9 & 17 \\
\hline $0.600<\mathrm{TE}<0.700$ & 3 & 5 & 0.86 \\
\hline Average & 0.85 & 0.87 & 0.52 \\
\hline Minimum & 0.54 & 0.52 & 0.98 \\
\hline Maximum & 0.98 & 0.98 & \\
\hline
\end{tabular}

The coefficient of seed is negative and highly significant indicating that nearly $30 \%$ output will decline with increase in one $\mathrm{kg}$ of seed. The average usage of seed is 76.7 which is also exceeding the recommended quantity. The recommended seed rate per hectare in paddy production happens to be $65 \mathrm{~kg}$ (crop protection guide, TNAU and Department of Agriculture). So we can conclude that to get better yield the tank irrigated farms may reduce the usage of seed. The coefficient of pesticide is also negative and highly significant indicates that to increase the yield we could reduce the pesticide usage. The improper combination of pesticide will not only affect the productivity of soil but it could also affect the quality of ground water in the long run (Nyuyen, 1999; Nguyen et al., 2000; NFDC, 1998; Sarah and Brad, 1993). Both soil and ground water are important sources of production and therefore, these resources should be sustained for the future generation in order to maintain their welfare level.

It is observed that MLE for $\gamma$ is 0.81 and highly significant (Table 2). It is consistent with the theory that true $\gamma$-value should be greater than zero. The value of $\gamma$-estimate is significantly different from one, indicating that random error is playing significant role to explain the variation in rice production and this is normal especially in case of agriculture where uncertainty is assumed to be a main source of variation. This implies that stochastic frontier model is significantly different from deterministic frontier, which does not include random error. However, it should be noted that
81 percent variation in output is due to technical inefficiency and 17 percent is due to stochastic random error.

In order to investigate the determinants of inefficiency we estimated the technical inefficiency model elaborated above as equation (5), where inefficiency is assumed to be dependent variable. We used age of the respondent as an independent variable and its coefficient is highly significant and negative in tank irrigated farms, indicating that as the age of the head of household increases the inefficiency level decreases. The coefficient area is positive and highly significant according to the priori expectations.

The frequency distribution of technical inefficiency is reported in table 3. The maximum and minimum values of technical efficiency are 98 and 52 percent, respectively. The mean technical efficiency in rice production is 86 percent and 27 farmers are more than 90 percent technically efficient and 54 farmers are more than 80 percent but less than 90 percent technically efficient. 17 farmers are less than 80 percent but more than 70 percent technically efficient. Eight farmers are in the range of 60-70 percent technically efficient.

Seed and pesticide have negative and significant impact on output, but NPK nutrients, Labour hours and machine hours are positive and highly significant. But Pesticide usage is heavy which is exceeded the recommended quantity which will affect the soil for getting better 
yield. It is also advisable to the tank irrigated farms to reduce the usage of seed according to the recommended one. The role of the extension department needs to be strengthened in the study area which seems to be very poor in the present situation, old farmers are motivated to participate in agricultural related activities with the help of young generations and has better ability to adopt modern technology to make timely decisions. On an average farmers are 86 per cent technically efficient implying that little potential exists that can be explored to improve resource use efficiency in rice production. Therefore, in order to improve rice productivity in the long run, production function needs to be shifted upward with the help of new production technologies. It implies that research institutes should focus for the development of high yielding and more qualitative varieties and this required more investment on research related activities.

\section{References}

Abedullah, et al. 2007. "Aanalysis of technical efficiency of Rice production in punjab (pakistan) Implications for Future Investment Strategies" Pak. Econ. Soc. Rev., 45(2): 231-244.

Aigner, D.J., C.A.K. Lovell and Schmidt, P. 1977. "Formulation and Estimation of Stochastic Frontier Production Function Models," J. Econometrics, 6(1): 21-37.

Battese, G.E. and Coelli, T.J. 1995. 'A model for technical inefficiency effects in a stochastic frontier production function for panel data'. Empirical Econ., 20: 325332, 1995.

Kalirajan, K. and J.C. Flinn. 1983. "The Measurement of Farm Specific Technical
Efficiency", Pak. J. Appl. Econometrics, 11(2): 167-180.

Kodde, D.A. and F.C. Palm. 1986. Wald criteria for jointly testing equality and inequality Restrictions. Econometrica, 54: 12431248 .

Meeusen, W. and J. van den Broeck. 1997. "Efficiency Estimation from CobbDouglas Production Functions with Composed Error", Int. Econ. Rev., 18: 435-444.

NFDC. 1998. Annual Fertilizer Review, 19971998. NFDC Publication \# 6/98. National Fertilizer Development Corporation, Islamabad. Pakistan.

Nguyen, H.D., et al. 2000. Impact of AgroChemical Use on Productivity and Health in Vietnam. Report submitted to International Development Research Centre (IDRC),

Nyuyen, H.D. 1999. Fertilizer Market in Vietnam: Impact of Agro-chemical Use on Productivity and Health. Economy and Environment Case Studies in Vietnam, Economy and Environment Program for Southeast Asia, pp. 53-54.

Ottawa, Canada. http://203.116.43.77/ publications/research1/ACF122.html.

Sarah, L.B. and C.J. Brad. 1993. Agriculture's effect on environmental quality: Key Management issues. Working Paper No. WQ-17-W, 7/93. Cooperative Extension Service, Purdue University and US Department of Agriculture.

Sharma, V.P. and Datta, K.K. 1997. "Technical efficiency in wheat production on reclaimed alkali Soils, Productivity" Indian J. Agri. Economics, 38(2): 334. 1997.

\section{How to cite this article:}

Vasanthi, R., Sivasankari, B., Gitanjali, J. and Paramasivam, R. 2017. Efficiency Analysis of Paddy Production in Tank Irrigated Systems of Southern Zone in Tamil Nadu, India. Int.J.Curr.Microbiol.App.Sci. 6(6): 1161-1167. doi: https://doi.org/10.20546/ijcmas.2017.606.134 